Indexed by

\title{
Scopus
}

\section{PRIORITY SEARCH SIMULATION FOR FLOOD EVACUATION ROUTES USING FUZZY AHP APPROACH}

Crossref

\author{
T. Brenda Chandrawati \\ Universitas Indonesia, \\ Faculty of Engineering, \\ Department of Electrical \\ Engineering, \\ Depok, \\ Indonesia
}

\author{
Anak Agung Putri Ratna \\ Universitas Indonesia, \\ Faculty of Engineering, \\ Department of Electrical \\ Engineering, \\ Depok, \\ Indonesia
}

\author{
Riri Fitri Sari \\ Universitas Indonesia, \\ Faculty of Engineering, \\ Department of Electrical \\ Engineering, \\ Depok, \\ Indonesia
}

KOBSON

Soogle

Key words: flood evacuation simulation, safe route, obstacles, fuzzy AHP, weight, priority route doi:10.5937/jaes0-29797

Cite article:

Brenda Chandrawati T., Agung Putri Ratna A., Fitri Sari R. (2022) PRIORITY SEARCH SIMULATION FOR FLOOD EVACUATION ROUTES USING FUZZY AHP APPROACH, Journal of Applied Engineering Science, 20(1), 19 - 28, DOI:10.5937/ jaes0-29797

Online aceess of full paper is available at: www.engineeringscience.rs/browse-issues 


\title{
PRIORITY SEARCH SIMULATION FOR FLOOD EVACUATION ROUTES USING FUZZY AHP APPROACH
}

\author{
T. Brenda Chandrawati*, Anak Agung Putri Ratna, Riri Fitri Sari \\ Universitas Indonesia, Faculty of Engineering, Department of Electrical Engineering, Depok, Indonesia
}

A flood is an event of an increase in water volume above the standard limit due to increased rainfall, rising sea levels, storms, and others that result in submerging an area. Floods are disasters that can cause damage and loss of property, disrupt community activities and even cause loss of life. The central defiance to rescue flood victims is choosing a safe route for flood victims to reach the evacuation site. To be able to choose a safe route for flood victims, a flood evacuation simulation is made. Flood evacuation simulation is part of the game that has been created and aims to provide education about the weight of the obstacle that needs to be considered in selecting routes for flood victims. In this flood evacuation simulation, each road has obstacles. The method proposed for choosing safe routes for flood victims is the Fuzzy-based Analytical Hierarchy Process (Fuzzy AHP). The calculation of road route weight using the Fuzzy AHP method will produce the weight for each route. The smallest weight route shows the priority route and the safe route for flood victims to pass. In this case, the Fuzzy AHP method's calculation produces the lowest weight of 0.02347 , which is achieved by route 5 , the route passing through $S-a-b-d-D$. This route is a priority route that is safe for flood victims to pass through.

Key words: flood evacuation simulation, safe route, obstacles, fuzzy AHP, weight, priority route

\section{INTRODUCTION}

Flood disaster is one of the natural disasters that often occurs in any region in the world. From National Disaster Management Agency (BNPB) data, it is known that throughout 2020 there were 1,065 flood events in Indonesia. Flooding is an event of stagnant water in an area due to an increase in water volume. The cause of the flooding is basically due to three things. First, human activities cause spatial changes and impact natural changes, including human settlements along river banks, littering behavior, excessive use of groundwater, illegal logging behavior, social behavior in disposing of garbage, etc. Second, natural events result in flood disasters such as high rainfall, storms, sea-level rise, etc. Third, environmental degradation such as silting rivers due to sedimentation, narrowing river channels, loss of vegetation in green areas, and others.

Flood disasters result in physical, socio-economic, and human life damage [1]. Flood-affected areas will experience many losses, damage to people's houses, social and public facilities, environmental damage, outbreaks of disease, victims being injured, washed away, lost, or even death. Losses get bigger if economic and government activities are disrupted. The government has taken various measures to prevent flooding. This aims to minimize the damage caused by flooding. However, suppose the rainfall is getting higher, and the water starts to stagnate. In that case, one individual mitigation step needs to be done by placing sandbags around the house [2, 3], turning on the pump to suck up the stagnant water, and dumping it into the river. If the flood starts to spread and the water is getting higher, it is necessary to evacuate the flood victims. Evacuation of victims is the most effec- tive way to minimize casualties. The evacuation action involves many aspects related to the stages of the evacuation process [4]. Evacuation is a process of searching for or moving people who are in a dangerous place to a safer place [5]. Evacuation is intended to search and rescue disaster victims, reduce the increase in the number of casualties in a disaster and collect data on disaster victims. There are many challenges in evacuating flood victims, including determining a safe route for flood victims to pass to a predetermined evacuation location. Route selection is vital because of the obstacles faced by flood victims, including the depth of water on the road that hinders victims' movement [6]. The vulnerability of certain groups is also a challenge during an evacuation [7]. Vulnerability is defined as a condition/nature or human behavior that causes the inability to face danger or threats. The distance from the river also influences the extent and size of the flood [8]. The distance of the road from the river is a consideration in choosing an evacuation route. Drainage [9] and surface roughness [10] are also considered to determine the level of vulnerability of an area due to flooding.

Floods that occur in developing countries are a result of human activity. Efforts to reduce floods require education and learning for the community regarding flood disasters, both directly and indirectly. Through hands-on education and learning, people gain knowledge, abilities, skills, and perceptions to prepare for and cope with the impact of disasters. Meanwhile, through indirect education and learning, the community will access all information related to matters that can help reduce vulnerability to disasters $[11,12]$. Learning with games is an 
educational method to convey information, knowledge, and imitative experiences about management when a disaster occurs [13]. Games that combine practical and entertainment aspects are called serious games. A serious game is a game that aims for education [14]. One of the serious games that focus on flood safety training has a real-world scenario. Players are instructed to take the right action when a flood occurs [15]. The advantage of the serious game about flooding is that it better understands the dangers of natural disasters and how to deal with them [16]. The serious game provides a pleasant experience in learning about serious problems [17]; it can also increase public knowledge and awareness of floods [18]. Thus, it can be seen that the serious game can be used to carry out simulations aimed at increasing community understanding and skills regarding disaster situations and how to overcome them.

Based on the advantages previously mentioned, a game has been created that educates the public to make flood prevention efforts and select safe evacuation routes during a flood, namely Flood Disaster Prevention Game [19]. This serious game will interact with players to teach about goals, problem-solving, the process of interaction, and adaptation [20]. Flood Prevention Game consists of several game stages. The first stage is a habit game: to do the correct behavior of disposing of garbage and making biopore holes. The second stage is a rescue game. The second stage in this game invites players to take rescue actions when a flood occurs, carry out activities to reduce the water that has inundated the surrounding area by heaping sandbags, and install pumps to discharge water into the nearest river. The part of the game is a simulation of finding the safest route for flood victims from several alternative routes. Every road on every route has various obstacles.

The constraints faced by flood victims on each road are expressed by a value called weight. The amount of weight for each road depends on the weight of the obstacle. After the weight on each road in a route is obtained, a decision-making process that involves five predetermined criteria is required. The criteria, in this case, are indicated by constraints. These criteria are considered in the decision-making process. In this case, the method used in decision-making, the evacuation route's priority, is the Analytical Hierarchy Process (AHP) method. The AHP method was developed by Thomas Saaty [21]. AHP method is a decision-making method with many complex criteria. AHP method is a decision-making method that combines qualitative and quantitative approaches. AHP method has a weakness of subjectivity. This subjectivity can be reduced by modifying the system using fuzzy logic. The fuzzy logic that is combined in AHP aims to get a better solution. This method is often called the Fuzzy Analytical Hierarchy Process (Fuzzy AHP). The fuzzy AHP approach is used in this study because it helps decision-makers understand the problem's context easily. After all, the problem is expressed in a hierarchical form [22], fuzzy set theory helps to consider the vagueness of the assessment criteria [23], a consistency analysis shows the experts' reliability [24], and it can be used to perform research with a small sample [25]. AHP fuzzy method calculates the weight criteria for finding a route and provides a safe route priority order.

AHP method can be used for decision making in various cases, including cases of diversification of activities related to fisheries [26], reinforcement of hydropower strategy [27], dynamics of lean-green practices [28], agriculture, planning and management of agricultural land [29-31], mapping terrain with sufficient angles and temperatures to provide the right conditions for the development of a bee population [32], essential indicators for the development and assessment of organic agriculture [33], and disaster [34, 35]. According to [36], the Fuzzy AHP method is the second technique after AHP, which is most widely used to assist in the decision-making process. The Fuzzy AHP method can be used to resolve various cases. Research that uses Fuzzy AHP includes risk analysis in Green Supply Chain practices [37], the process of selecting the right supplier, the winner of bidding in a construction project [38, 39], and agriculture [40-42]. The Fuzzy AHP method is also widely used in decision-making related to earthquakes $[43,44]$ and evacuation sites [45]. The Fuzzy AHP model can be used to assess the flood risk [46, 47]. Several studies using the Fuzzy AHP method combined with GIS were used to evaluate flood risk $[49,50]$. Fuzzy AHP adaptation is used to weight the attributes and sub-attributes of criteria in measuring flood resistance (Composite Flood Resilient Index) [51] and the use of Fuzzy AHP to determine the selection of alternative flood control by taking economic, social, and environmental considerations into account $[11,52]$. This study aims to design a priority search simulation for flood victims' evacuation routes using the Fuzzy AHP method. The simulation of finding priority routes for flood victims is part of the serious game. AHP fuzzy method generates a priority sequence of routes by showing the criteria' weight order starting from the smallest. The route with the lowest weight represents the obstacles that flood victims can face. The route with the smallest weight is the safest route for flood victims to pass.

\section{RESEARCH METHOD}

\section{Evacuation Routes for Flood Victim}

The simulation of route selection for flood victims will be discussed in this section. As previously mentioned, a game has been created that aims to educate the public regarding flood prevention efforts and the selection of safe evacuation routes in the event of a flood, namely the Flood Disaster Prevention Game [20] and simulated safe route selection in games requiring environmental modeling. Road modeling and obstacle design based on the Semarang City landscape. Semarang City is the capital of the Central Java province of Indonesia and is the fifth largest city in Indonesia. Semarang City has an administrative area of $373.70 \mathrm{~km}^{2}$. Semarang City has an alti- 
tude from $2 \mathrm{~m}$ below sea level to $340 \mathrm{~m}$ above sea level with a slope of $0 \%$ to $45 \%$. Semarang City has a narrow lowland area and a hilly area that extends from the west to the east side of the city. The lowland area of the city of Semarang is a flood area caused by the overflowing of large rivers, including Kali Garang (Banjir Kanal Barat River), Pengkol River, Beringin River, Asin River, Banger River, and Banjir Kanal Timur River. Annual floods and peaks often hit lowland areas or so-called lower cities during the rainy season. Figure 1 shows a flood map for the city of Semarang.

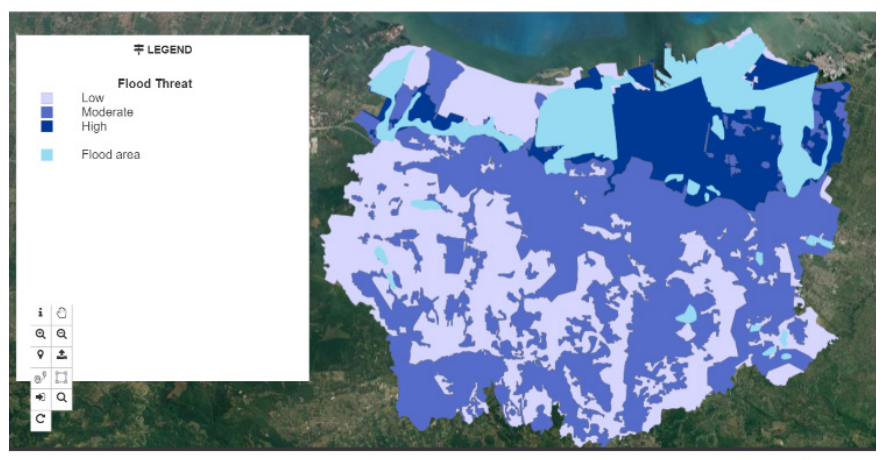

Figure 1: Semarang city flood map [48]

Environmental modeling of the path that the flood victims traversed is shown in Figure 2. S indicates the center of the flood disaster, and D is the evacuation location which is the destination of the flood victims.

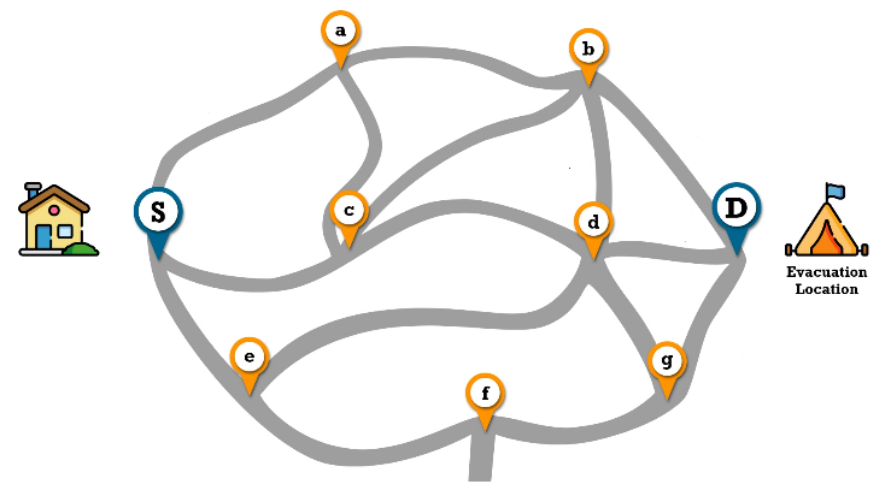

Figure 2: Simulation route model [49]

From Figure 2, it can be seen that each node (a, b..., g) represents a crossroads. Arcs are connecting nodes model roads between intersections [50]. In Figure 2, there are 24 alternative routes that flood victims can pass. Table 1 shows 24 route alternatives. Each route consists of several roads, which are between 3 to 8 roads. Every road will have obstacles that obstruct the flood victims who will pass the route. Flood victims will go through a route to be safely passed to reach the designated evacuation location.

Obstacles on each road will hamper the journey and slow down flood victims to reach the evacuation site. It is also possible that the road will be dangerous if crossed. Obstacles faced by flood victims on each route are slippery roads, stagnant water on the road, a river located close to the road that is dangerous for people who cross the road, drainage road, and the level of vulnerability of flood victims.

Table 1: Alternative Route [50]

\begin{tabular}{|c|c|c|c|}
\hline $\begin{array}{c}\text { Name of } \\
\text { route }\end{array}$ & Route & $\begin{array}{c}\text { Name of } \\
\text { route }\end{array}$ & Route \\
\hline R1 & S-a-b-D & R13 & S-a-b-c-d-D \\
\hline R2 & S-c-b-D & R14 & S-a-c-b-d-D \\
\hline R3 & S-c-d-D & R15 & S-c-b-d-g-D \\
\hline R4 & S-e-d-D & R16 & S-e-f-g-d-D \\
\hline R5 & S-a-b-d-D & R17 & S-a-b-c-d-g-D \\
\hline R6 & S-a-c-b-D & R18 & S-a-c-b-d-g-D \\
\hline R7 & S-c-b-d-D & R19 & S-c-d-e-f-g-D \\
\hline R8 & S-c-d-g-D & R20 & S-e-f-g-b-d-D \\
\hline R9 & S-e-d-b-D & R21 & S-a-b-d-e-f-g-D \\
\hline R10 & S-e-d-g-D & R22 & S-c-b-d-e-f-g-D \\
\hline R11 & S-e-f-g-D & R23 & S-a-b-c-d-e-f-g-D \\
\hline R12 & S-a-b-d-g-D & R24 & S-a-c-b-d-e-f-g-D \\
\hline
\end{tabular}

\section{Analytical Hierarchy Process}

Analytical Hierarchy Process (AHP) is a decision support method developed by Thomas L. Saaty [21]. The AHP method ranks decisions alternative and selects one of the best criteria for multi-criteria cases. This method combines quantitative and qualitative factors that are used to evaluate existing alternatives. AHP method arranges complex multi-criteria problems into multi-levels by understanding decision-makers by forming a hierarchy [3]. The hierarchy, which consists of several levels, can be described as follows: the first level defines the objectives, the second level is the criteria, the next level is the sub-criteria, and the last is an alternative decision. With a hierarchy, a complex problem will look more structured. The AHP method uses a number scale that represents the intensity of interest.

The steps in the AHP method are as follows [26]:

1. Define the problem and set goals. This stage in the AHP method is to develop alternatives. The difficulties encountered and the objectives to be achieved are arranged in a hierarchical form. Deciding the issues faced in a hierarchy aims to review complex problems from the detailed and measurable side. Figure 3. shows the hierarchical structure of the AHP method in this case.

The purpose of resolving this case is to find a safe route for flood victims to cross. Table 2 provides information on the criteria for this case.

2. Arrange a pairwise comparison matrix. This paired comparison matrix represents the relative importance of an element about the objectives or criteria given. Pairwise comparison is carried out for each criterion and alternative. Each component is com- 
pared with other features.

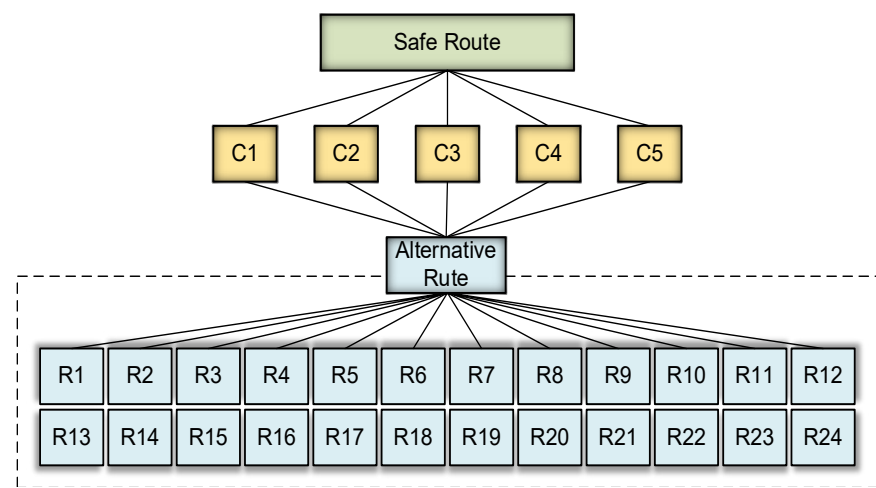

Figure 3: The AHP hierarchical structure of priority search for evacuation routes [49]

Table 2: Description of the criteria code

\begin{tabular}{|c|c|}
\hline Code & Explanation \\
\hline C1 & The level of road slipperiness \\
\hline C2 & The availability of stagnant water on the street \\
\hline C3 & The distance of the river from the road \\
\hline C4 & Road drainage \\
\hline C5 & $\begin{array}{c}\text { The vulnerability of flood victims who will get } \\
\text { through the road }\end{array}$ \\
\hline
\end{tabular}

Pairwise comparisons of elements are carried out at each level of the hierarchy. The pairwise comparison aims to obtain the degree of the importance of the factors in a qualitative manner. The change of qualitative to quantitative view uses a rating scale in the form of numbers, which can be seen in Table 3 .

In this phase, a comparative assessment of one criterion with another is made in the form of a paired matrix using the AHP importance intensity scale in Table 3.

Table 3: Pairwise scale comparison Saaty [21]

\begin{tabular}{|c|c|}
\hline $\begin{array}{l}\text { Intensity of } \\
\text { Importance }\end{array}$ & Explanation \\
\hline 1 & $\begin{array}{l}\text { Two activities contribute equally to the } \\
\text { objective. }\end{array}$ \\
\hline 3 & $\begin{array}{l}\text { Experience and judgment slightly } \\
\text { favor one activity over another. }\end{array}$ \\
\hline 5 & $\begin{array}{l}\text { Experience and judgment strongly } \\
\text { favor one activity over another. }\end{array}$ \\
\hline 7 & $\begin{array}{l}\text { An activity is favored very strongly } \\
\text { over another; its dominance demon- } \\
\text { strated in practice }\end{array}$ \\
\hline 9 & $\begin{array}{l}\text { The evidence favoring one activity } \\
\text { over another is of the highest possible } \\
\text { order of affirmation. }\end{array}$ \\
\hline $2,4,6,8$ & $\begin{array}{l}\text { The value between two values of con- } \\
\text { sideration that are close together }\end{array}$ \\
\hline
\end{tabular}

Sometimes, in pairwise comparison judgments, there are often inconsistent preferences by decision-makers.
This stage was carried out, aiming to determine the value of the $C R$ ratio consistency. If $C R<0.1$, then the specified pairwise comparison matrix is consistent. Conversely, if $\mathrm{CR}>0.1$, then the pairwise comparison matrix is not consistent. Pairwise comparisons between criteria in the search for safe routes for flood victims are shown in Table 4.

Table 4: Pairwise comparison matrix for criteria

\begin{tabular}{|c|c|c|c|c|c|}
\hline Criteria & C1 & C2 & C3 & C4 & C5 \\
\hline C1 & 1 & 1 & 0.333 & 1 & 0.2 \\
\hline C2 & 1 & 1 & 0.2 & 1 & 0.2 \\
\hline C3 & 3 & 5 & 1 & 3 & 0.333 \\
\hline C4 & 1 & 1 & 0.333 & 1 & 0.2 \\
\hline C5 & 5 & 5 & 3 & 5 & 1 \\
\hline
\end{tabular}

To calculate the consistency index for each pairwise matrix comparison, use equation (1):

$C l=\frac{\lambda_{\max }-n}{n-1}$

$\lambda_{\max }$ is the largest eigenvalue of the comparison matrix, and $\mathrm{n}$ is the dimension of the matrix.

The consistency ratio is calculated using the equation:

$C R=\frac{C l}{R I(n)} \cdot 100 \%$

$\mathrm{RI}(\mathrm{n})$ is a random index, depending on $\mathrm{n}$. In this case, $\mathrm{RI}(\mathrm{n})$ uses a table of the random index from [51] because $n>15$.

3. Determine the weight of each element by calculating the eigenvectors of each paired comparison matrix. This step is carried out to synthesize choices in determining the priority of features at the lowest hierarchy level to reach the goal. The element with the highest weight has priority handling.

\section{Fuzzy Set}

The Fuzzy set theory of Zadeh is a theory that explains the boundaries of an object that are not defined sharply, studying vague conceptual phenomena precisely, which are related to human subjective assessment [52].

The linguistic variable is a variable whose value is qualitative. It is useful to solve problems that are not clear and uncertain, where the problem cannot be defined quantitatively.

\section{Fuzzy Analytical Hierarchy Process}

The AHP method has the drawback of subjectivity. In the AHP method, experts' decision is a linguistic perception, so the original AHP scale must be approached in another way. A fuzzy logic approach is an approach that should be considered to be combined with the AHP method. Fuzzy logic can model the uncertainty contained in the judgment (preference) of decision-makers. Pairwise compare-son matrices expressed in fuzzy numbers can show information, as is the case with conventional AHPs. The Fuzzy AHP method will also increase solution flexibility [38]. 
The sense of comparison matrix of the AHP method is from 1 to 9. The AHP method's scale is transformed into a fuzzy triangular scale, as can be seen in Table 5 .

Table 5: Linguistic scale of importance weight of attribute

\begin{tabular}{|c|c|c|}
\hline Linguistic Variable & AHP Scale & $\begin{array}{c}\text { Triangular Fuzzy } \\
\text { Scale }\end{array}$ \\
\hline Just Equal & 1 & $\begin{array}{c}(1,1,1) \text { if diagonal } \\
\text { and }(1,1,3) \text { others }\end{array}$ \\
\hline Moderately & 3 & $(1,3,5)$ \\
\hline Strongly & 5 & $(3,5,7)$ \\
\hline Very Strongly & 7 & $(5,7,9)$ \\
\hline Extremely & 9 & $(7,9,9)$ \\
\hline
\end{tabular}

The steps in the Fuzzy AHP method are as follows [53]:

1. Calculate the value of fuzzy synthetic extent using the formula:

$S_{i}=\Sigma_{j=1}^{m} M_{g i}^{j} \otimes\left[\sum_{i=1}^{n} \Sigma_{j=1}^{m} M_{g i}^{j}\right]^{-1}$

With

$\sum_{j=1}^{m} M_{g i}^{j}=\left(\sum_{j=1}^{m} I_{j}, \Sigma_{j=1}^{m} m_{j}, \Sigma_{j=1}^{m} u_{j}\right)$

and $\otimes$ is a dot product operator.

$\mathrm{M}_{\mathrm{gi}}^{\mathrm{j}}$ is a triangular fuzzy number and defined as a triplet number.

The value of $\left[\sum_{i=1}^{n} \sum_{j=1}^{m} M_{g i}^{j}\right]^{-1}$ is obtained by the formula

$\left[\sum_{i=1}^{n} \sum_{j=1}^{m} M_{g i}^{j}\right]^{-1}=\left(\frac{1}{\sum_{i=1}^{n} u_{i}}, \frac{1}{\sum_{i=1}^{n} m_{i}}, \frac{1}{\sum_{i=1}^{n} I_{i}}\right)$

Table 6 shows the comparison matrix between criteria made using triangular fuzzy numbers. The next step is to check the consistency ratio in the pairwise comparison matrix based on the consistency index calculation. Equations (3) to (5) are used to calculate each criterion's synthetic fuzzy value.

Table 6: Pairwise comparison matrix of criteria in the triangular fuzzy number

\begin{tabular}{|c|c|c|c|c|c|}
\hline Criteria & C1 & C2 & C3 & C4 & C5 \\
\hline C1 & $(1,1,1)$ & $(1,1,1)$ & $(1 / 5,1 / 3,1)$ & $(1,1,1)$ & $(1 / 7,1 / 5,1 / 3)$ \\
\hline C2 & $(1,1,1)$ & $(1,1,1)$ & $(1 / 7,1 / 5,1 / 3)$ & $(1,1,1)$ & $(1 / 7,1 / 5,1 / 3)$ \\
\hline C3 & $(1,3,5)$ & $(3,5,7)$ & $(1,1,1)$ & $(1,3,5)$ & $(1 / 5,1 / 3,1)$ \\
\hline C4 & $(1,1,1)$ & $(1,1,1)$ & $(1 / 5,1 / 3,1)$ & $(1,1,1)$ & $(1 / 7,1 / 5,1 / 3)$ \\
\hline C5 & $(3,5,7)$ & $(3,5,7)$ & $(1,3,5)$ & $(3,5,7)$ & $(1,1,1)$ \\
\hline
\end{tabular}

2. Calculate the ratio of the possible levels between fuzzy numbers.

If two fuzzy triangular numbers are known, $M_{1}=\left(l_{1}, m_{1}, u_{1}\right)$ and $M_{2}=\left(I_{2}, m_{2}, u_{2}\right)$ with a probability level $\left(M_{2} \geq M_{1}\right)$ then a comparison of the probability level can be calculated using the formula:

$V\left(\tilde{M}_{2} \geq \tilde{M}_{1}\right)=\sup _{y \geq x}\left[\min \left(\mu_{\tilde{M}_{1}}(x), \mu_{\tilde{M}_{2}}(y)\right)\right]$

Figure 4 shows the intersection between $M_{1}$ and $M_{2}$.

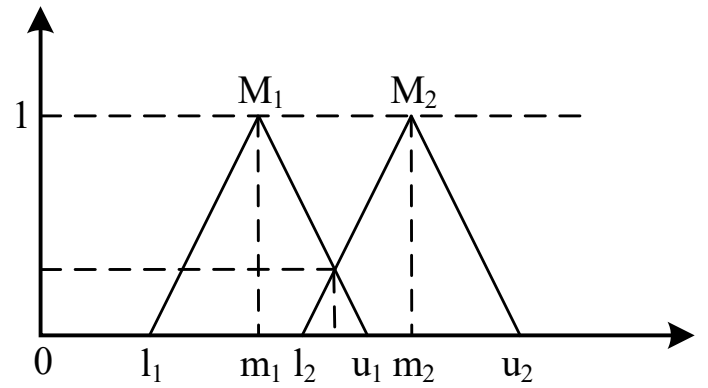

Figure 4: The intersection between M1 and M2 [25]

Equation (6) can be expressed with

$$
V\left(\tilde{M}_{2} \geq \tilde{M}_{1}\right)=\left\{\begin{array}{c}
1, \text { if } m_{2} \geq m_{1} \\
0, \text { if } I_{1} \geq u_{2} \\
\frac{\left(I_{1}-u_{2}\right)}{\left(m_{2}-u_{2}\right)-\left(m_{1}-I_{1}\right)}, \text { otherwise }
\end{array}\right.
$$

3. Calculate the possible level of fuzzy numbers.

The possible levels of fuzzy numbers are defined as follows:

$d^{\prime}\left(A_{i}\right)=\min \left(V\left(\tilde{M}_{2} \geq \tilde{M}_{1}\right)\right)$

$k=1,2, \ldots n ; k \neq i$

So the weight vector is given as

$W^{\prime}=\left[d^{\prime}\left(A_{1}\right), d^{\prime}\left(A_{2}\right) \ldots d^{\prime}\left(A_{n}\right)\right]^{T}$

4. Normalize the weight vector

Normalization of fuzzy numbers, which show the equation does weight vector:

$W=\left[d\left(A_{1}\right), d\left(A_{2}\right) \ldots d\left(A_{n}\right)\right]^{T}$

\section{RESULT AND DISCUSSION}

In this section, numerical calculations are performed from the search for safe routes for flood victims. Two methods, namely AHP and Fuzzy AHP, are used to perform calculations. The criteria in both cases are the same: the level of road slipperiness, the availability of stagnant water on the street, rivers around the road to be passed, the road drainage, and the level of vulnerability flood victims who will get through the pathway. This criterion is an obstacle for each path, and its value is determined.

\section{AHP Method}

\section{- Consistency Index and Consistency Ratio}

After calculating the AHP method's stages and using the $\mathrm{RI}$ table in [51], we get $\mathrm{Cl}=0.039$ and $\mathrm{CR}=0.035$. With $\mathrm{CR}<0.1$, the comparison between criteria is consistent.

\section{- Weight of each criterion}

After calculation, the weight of each criterion is as follows:

1. The criterion for the level of road slipperiness weight 0.08613 
2. The weight of the criterion for water level inundated on the road is weighted 0.08066

3. The criterion for the proximity of the river from the road to be passed by flood victims weights 0.26157

4. The weight value of the road drainage criteria is equal to the weight criterion of the road slipperiness level, which is 0.08613

5. The last criterion, namely the vulnerability of flood victims, has a weight value of 0.48551 . This value is the highest compared to the weighted value of the other criteria.

After getting the weights for the five criteria, and the value for each criterion for each alternative, the total weight for each alternative can be calculated. The final weight value of each route can be seen in Figure 5 .

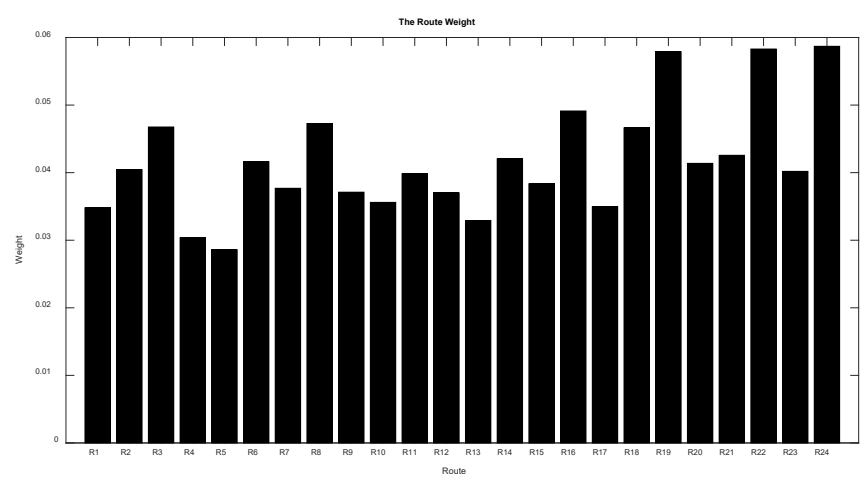

Figure 5: The route weight by AHP method

From Figure 6, we can see that the fifth route ranks first with a weight of 0.02858 . This situation shows that the fifth route is the safest route for flood victims to pass. The safest route is a pathway that has an undangerous obstacle. The safest route is the priority route that flood victims will pass.

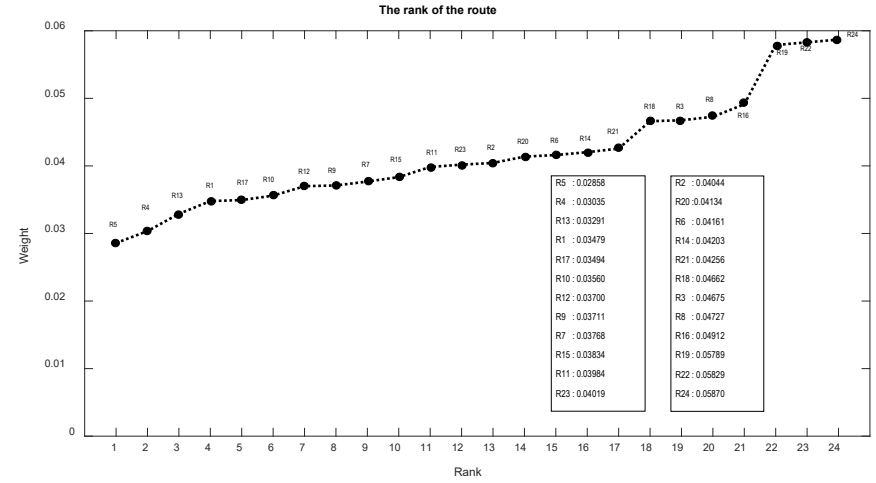

Figure 6: Rank weights using the AHP method

\section{Fuzzy AHP Method}

The fuzzy AHP method is the development of the AHP method based on the fuzzy approach. The Fuzzy AHP method uses fuzzy triangle numbers that are used to represent the comparative assessment of decision-makers in pairs to determine the last priority. The principle of comparing fuzzy numbers was developed to determine each route's weight vector with specific criteria. The pre- determined criteria are the obstacles faced by flood victims on each road in a course. The priority weights for each route are calculated, and based on these calculations, the route that has the smallest weight becomes the priority route to pass for flood victims because this route is the safest one.

\section{- Consistency Index and Consistency Ratio}

The comparison matrix's consistency index between criteria is calculated using Equations (1) and (2). Similar to the previous calculation, a comparison matrix consistency index of each alternative can be obtained. The consistency index is used to show how consistent the pairwise comparison matrix has been determined. After calculating the pairwise comparison metrics using equations (1) and (2), the results obtained are less than $10 \%$. This situation shows that the consistency of preference assessment in comparison is acceptable.

- Degree of Possibility and Normalization of Vector Weight

Fuzzy number comparisons are used to get weight vectors for all elements at each level of the hierarchy. The process of comparing fuzzy numbers uses synthetic fuzzy values, as shown in equation (6) to equation (8). The results of the calculation are the following:

$W=(0,1796 ; 0,26378 ; 0,78495 ; 0,0027 ; 1)^{\top}$

As above, the calculation process is also carried out on each alternative route based on each criterion to obtain the vector's weight.

After determining each criterion's vector weights, vector weight normalization is performed using equation (9). The calculation results obtained are $(0.0805 ; 0.111823$; $0.35183 ; 0.00121 ; 0.44823 ; 1)$. The normalization of vector weights for each alternative based on each criterion is also carried out with the same process.

\section{- Weight of each Route}

Each alternative's total weight can be calculated after getting the weights for the five criteria and the value for each alternative criterion. Figure 7 shows the final weights for each route alternative.

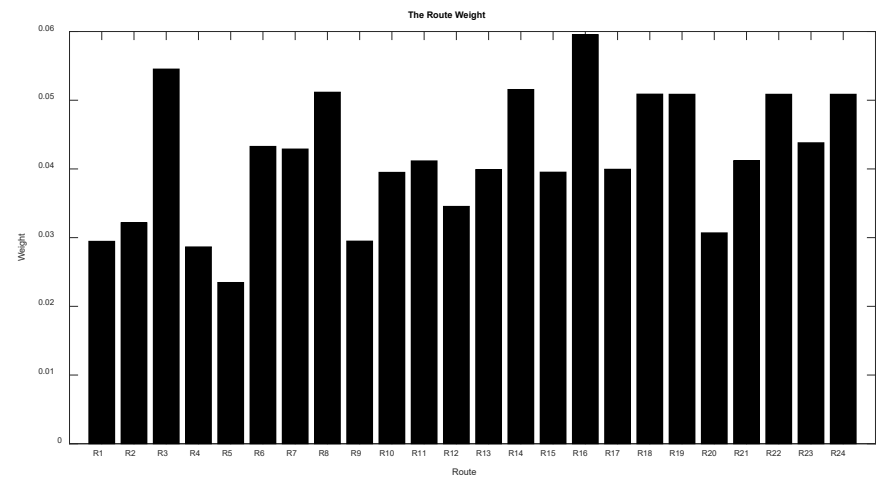

Figure 7: The route weights by the Fuzzy AHP method

To get the priority route decisions that the flood victims can pass, ranking the route's weight is carried out. In Figure 8, we can see ranking results for all route weights. 


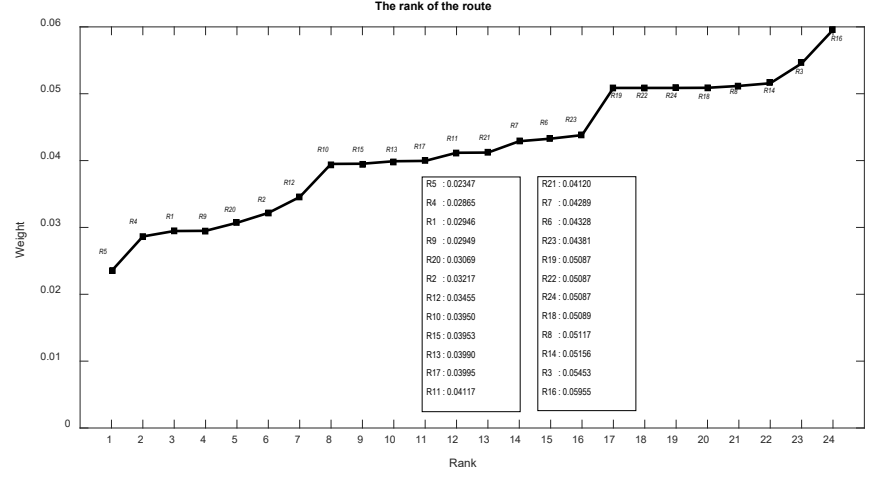

Figure 8: Final weight of routes and ranking by Fuzzy AHP

\section{Comparison of AHP and Fuzzy AHP Methods}

We can see that comparing each route's weight using the AHP and FAHP methods can be seen in Figure 9. From Figure 9 can be seen that the weight on each path calculated using the AHP method is different from the weight generated by the calculation using the Fuzzy AHP method.

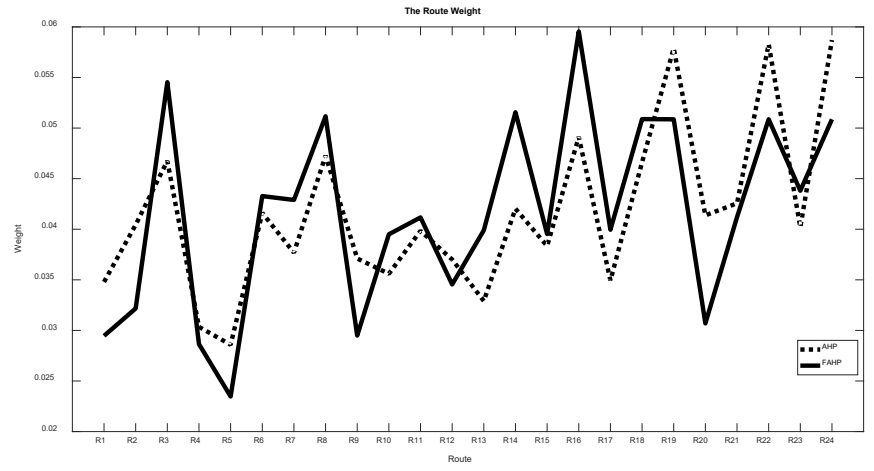

Figure 9: The route weights by AHP and Fuzzy AHP method

In the first route, the AHP method produces a weight of 0.03479 , but the Fuzzy AHP method weights 0.02946. Likewise, the weights provided by the AHP method are different from the weights produced by the Fuzzy AHP method.

The possible route weighting using the AHP method and the Fuzzy AHP method has different yields, both the number of weights generated and the order of weights from smallest to largest. The lowest weighting indicates that flood victims can pass the route because it has obstacles that flood victims can still face. The smallest weight route is the priority route for flood victims because of the slight danger level and safest route, while the route with the highest weight has a great danger level. The higher the weight held by a route, the greater the possible route is not safe to pass.

From Figure 10, we can see the route sequence starting from the route with the least weight to the largest weight route. Search priority route using Fuzzy AHP method produces R5 with the smallest weight. It shows that R5 is the priority route chosen because it has the slightest obstacle for the flood victims and is called a priority route.

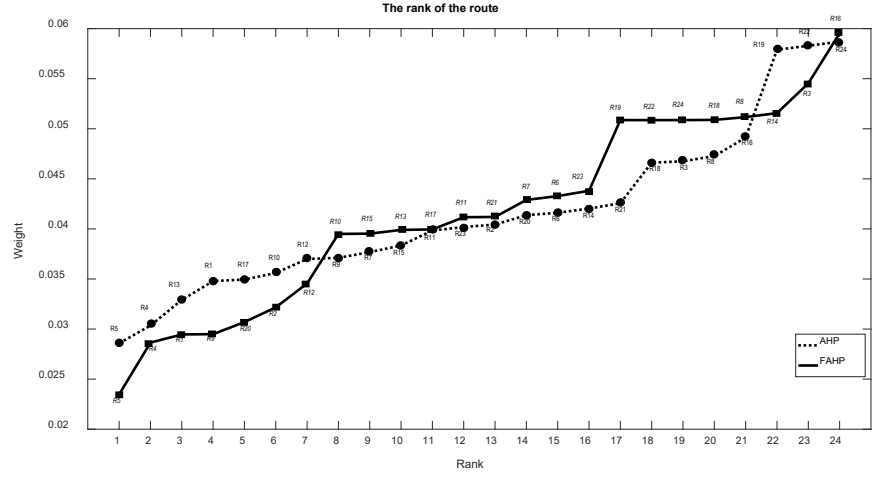

Figure 10: The route weight based on the ranking

\section{CONCLUSIONS}

Simulation of searching for priority routes using the AHP method is one way to obtain the safest route for flood victims. However, sometimes, natural language is preferred over numerical values in making decisions. Fuzzy AHP turned out to be more able to accommodate human judgment that had ambiguous values. Pairwise comparisons are a flexible way to solve real problems.

The model proposed in this study consists of five criteria: slippery roads, stagnant water on the road, rivers close to the road, roadside drainage, and the vulnerability of victims presented 24 alternative routes for flood victims. This model is used as a simulation of selecting priority paths when a flood occurs. This priority route is the safest route for flood victims to pass. Using the Fuzzy AHP method, the study results show that the fifth path, namely the S-a-b-d-D line, has the smallest weight, 0.02347 . It indicates that the $S-a-b-d-D$ route is a priority route that is safe for flood victims to pass through.

\section{ACKNOWLEDGEMENT}

The author would like obliged to the Ministry of Education and Culture of the Republic of Indonesia through the Directorate General of Research and Development for financial support for this research under the PDD Grant number NKB-22/UN2.RS/HKP.05.00/ 2020

\section{REFERENCES}

1. Lai, C., Chen, X., Chen, X., Wang, Z., Wu, X., Zhao, S. (2015). A fuzzy comprehensive evaluation model for flood risk based on the combination weight of game theory. Natural Hazards, vol. 77, no. 2, 12431259, DOI: 10.1007/s11069-015-1645-6.

2. Bischiniotis, K., de Moel, H., van den Homberg, M., Couasnon, A., Aerts, J., Nobre, G. G., Zsoter, E., van den Hurk, B. (2020). A framework for comparing permanent and forecast-based flood risk-reduction strategies. Science of the total environment, vol. 720, 137572, DOI: 10.1016/j.scitotenv.2020. 137572. 
3. Reeve, D., Badr, A. (2003), Performance of sandbags for domestic flood defence, in Proceedings of the Institution of Civil Engineers-Water and Maritime Engineering, vol. 156, no. 4: Thomas Telford Ltd, p. 341-349, DOI: 10.1680/ wame.2003.156.4.341.

4. Lim, M. B. B., Lim Jr, H. R., Piantanakulchai, M. (2019). Flood evacuation decision modeling for high risk urban area in the Philippines. Asia Pacific Management Review, vol. 24, no. 2, 106-113, DOI: 10.1016/j.apmrv.2019.01.001.

5. Saadatseresht, M., Mansourian, A., Taleai, M. (2009). Evacuation planning using multiobjective evolutionary optimization approach. European journal of operational research, vol. 198, no. 1, 305-314, DOI: 10.1016/j.ejor.2008.07.032.

6. Lee, H.-K., Hong, W.-H., Lee, Y.-H. (2019). Experimental study on the influence of water depth on the evacuation speed of elderly people in flood conditions. International journal of disaster risk reduction, vol. 39, 101198, DOI: 10.1016/j.ijdrr. 2019.101198.

7. Nakanishi, H., Black, J., Suenaga, Y. (2019). Investi-gating the flood evacuation behaviour of older people: A case study of a rural town in Japan. Research in Transportation Business \& Manage-ment, vol. 30, 100376, DOI: 10.1016/j.rtbm.2019. 100376.

8. Rahmati, O., Pourghasemi, H. R., Zeinivand, H. (2016). Flood susceptibility mapping using frequency ratio and weights-of-evidence models in the Golastan Province, Iran. Geocarto International, vol. 31, no. 1, 42-70, DOI: 10.1080/10106049. 2015.1041559

9. Talha, S., Maanan, M., Atika, H., Rhinane, H. (2019). Prediction of flash flood susceptibility using fuzzy analytical hierarchy process (Fahp) algorithms and Gis: a study case of guelmim region In Southwestern of Morocco. The International Archives of Photogrammetry, Remote Sensing and Spatial Information Sciences, vol. 42, 407-414, DOI: 10.5194/isprs-archives-XLII-4-W19-407-2019.

10. Sadek, M., Li, X. (2019). Low-cost solution for assessment of urban flash flood impacts using sentinel-2 satellite images and fuzzy analytic hierarchy process: a case study of ras ghareb city, Egypt. Advances in Civil Engineering, vol. 2019, DOI: 10.1155/2019/2561215.

11. Hoffmann, R., Blecha, D. (2020). Education and disaster vulnerability in Southeast Asia: Evidence and policy implications. Sustainability, vol. 12, no. 4, 1401, DOI: 10.3390/su12041401.

12. Kagawa, F., Selby, D. (2012). Ready for the storm: Education for disaster risk reduction and climate change adaptation and mitigation1. Journal of Education for Sustainable Development, vol. 6, no. 2, 207-217, DOI: 10.1177/0973408212475200.
13. Tsai, M.-H., Wen, M.-C., Chang, Y.-L., Kang, S.-C. (2015). Game-based education for disaster preven-tion. Al \& society, vol. 30, no. 4, 463-475, DOI: 10.1007/s00146-014-0562-7.

14. Mokhtar, N., Ismail, A., Muda, Z. (2019). Designing model of serious game for flood safety training. International Journal of Advanced Computer Scien-ce and Applications, vol. 10, no. 5, 331-339, DOI: 10.14569/IJACSA.2019.0100541.

15. Tena-Chollet, F., Tixier, J., Dandrieux, A., Slangen, P. (2017). Training decision-makers: Existing strategies for natural and technological crisis management and specifications of an improved simulation-based tool. Safety science, vol. 97, 144-153, DOI: 10.1016/j. ssci.2016.03.025.

16. Zaini, N. A., Noor, S. F. M., Zailani, S. Z. M. (2020). Design and Development of Flood Disaster Gamebased Learning based on Learning Domain. International Journal of Engineering and Advanced Technology vol. 9, no. 4, 679-685, DOI: $10.35940 /$ ijeat.

17. Tsai, M.-H., Chang, Y.-L., Kao, C., Kang, S.-C. (2015). The effectiveness of a flood protection computer game for disaster education. Visualization in Engineering, vol. 3, no. 1, 9, DOI: 10.1186/ s40327015-0021-7.

18. Rothkrantz, L. J., Fitrianie, S. (2018). Public Awareness and Education for Flooding Disasters. K. Holla, Ristvej, J., Titko,M (Eds.), Crisis Manage-ment: Theory and Practice. IntechOpen, London, pp. 181-202.

19. Chandrawati, T. B., Ratna, A. A. P., Sari, R. F. (2019), Implementing Bio-Inspired Algorithm for Pathfinding in Flood Disaster Prevention Game, in International Conference on Computational Science and Technology, Kota Kinabalu, Sabah, Malaysia: Springer, p. 23-31, DOI: 10.1007/978-981-15-0058-9_3.

20. Furuichi, M., Aibara, M., Yanagisawa, K. (2014), Design and implementation of serious games for training and education, in UKACC International Conference on Control: IEEE, p. 691-695, DOI: 10.1109/ CONTROL.2014.6915223.

21. Saaty, T. L. (2008). Decision making with the analytic hierarchy process. International journal of services sciences, vol. 1, no. 1, 83-98, DOI: 10.1504/ IJSSci.2008.01759.

22. Akbar, M. A., Shameem, M., Khan, A. A., Nadeem, M., Alsanad, A., Gumaei, A. (2020). A fuzzy analy-tical hierarchy process to prioritize the success factors of requirement change management in global software development. Journal of Software: Evolution and Process, e2292, DOI: 10.1002/smr. 2292.

23. Liu, Y., Eckert, C. M., Earl, C. (2020). A review of fuzzy AHP methods for decision-making with subjective judgements. Expert Systems with Applications, 113738, DOI: 10.1016/j.eswa.2020. 113738. 
24. 24. Yang, X.-I., Ding, J.-h., Hou, H. (2013). Application of a triangular fuzzy AHP approach for flood risk evaluation and response measures analysis. Natural Hazards, vol. 68, no. 2, 657-674, DOI: 10.1007/ s11069-013-0642-x.

25. Darko, A., Chan, A. P. C., Ameyaw, E. E., Owusu, E. K., Pärn, E., Edwards, D. J. (2019). Review of application of analytic hierarchy process (AHP) in construction. International journal of construction management, vol. 19 , no. 5, 436-452, DOI: 10.1080/15623599.2018.1452098.

26. Morgan, R. (2017). An investigation of constraints upon fisheries diversification using the Analytic Hierarchy Process (AHP). Marine Policy, vol. 86, 24-30, DOI: 10.1016/j.marpol.2017.05.037.

27. Singh, R. P., Nachtnebel, H. P. (2016). Analytical hierarchy process (AHP) application for rein-forcement of hydropower strategy in Nepal. Renew-able Sustainable Energy Reviews, vol. 55, 43-58, DOI: 10.1016/j.rser.2015.10.138.

28. Thanki, S., Govindan, K., Thakkar, J. (2016). An investigation on lean-green implementation practices in Indian SMEs using analytical hierarchy process (AHP) approach. Journal of Cleaner Production, vol. 135, 284-298, DOI: 10.1016/ j.jclepro.2016.06.105.

29. Davarpanah, S., Bonab, S. H., Khodaverdizadeh, M. (2016). Assessment and comparison of sustainable agriculture approach using a combination of AHP and TOPSIS. International Academic Journal of Economics, vol. 3, no. 9, 7-18.

30. Quoc, N. K., Prakash, I., Pham, B. T. (2019). Agricultural land suitability analysis for Yen Khe Hills (NgheAn, Vietnam) using analytic hierarchy process (AHP) combined with geographic information systems (GIS). Indian Journal of Ecology, vol. 46, no. 3, 445-454.

31. Rukanee, D., Sangchan, S., Choomjaihan, P. (2020). Assessment of the suitability of land use for agriculture by analytical hierarchy process: AHP in lower Prachinburi watershed, eastern Thailand. Agricultural Engineering International: CIGR Journal, vol. 22, no. 3, 19-26.

32. Romero-Gelvez, J. I., Beltrán-Fernández, S. V., Aristizabal, A. J., Zapata, S., Castañeda, M. (2020), Precision Agriculture Technology Evaluation using Combined AHP and GRA for Data Acquisition in Apiculture, in Workshops at the Third International Conference on Applied Informatics 2020, Ota, Nigeria.

33. Sajadian, M., Khoshbakht, K., Liaghati, H., Veisi, H., Damghani, A. M. (2017). Developing and quantifying indicators of organic farming using analytic hierarchy process. Ecological Indicators, vol. 83, 103-111, DOI: 10.1016/j.ecolind.2017.07.047.
34. Chakraborty, A., Joshi, P. (2016). Mapping disaster vulnerability in India using analytical hierarchy process. Geomatics, Natural Hazards and Risk, vol. 7, no. 1, 308-325, DOI: 10.1080/19475705.2014. 897656.

35. Kumar, R., Anbalagan, R. (2016). Landslide susceptibility mapping using analytical hierarchy process (AHP) in Tehri reservoir rim region, Uttarakhand. Journal of the Geological Society of India, vol. 87, no. 3, 271-286, DOI: 10.1007/s12594-016-0395-8.

36. Kubler, S., Robert, J., Derigent, W., Voisin, A., Le Traon, Y. (2016). A state-of the-art survey \& testbed of fuzzy AHP (FAHP) applications. Expert Systems with Applications, vol. 65, 398-422, DOI: 10.1016/j. eswa.2016.08.064.

37. Mangla, S. K., Kumar, P., Barua, M. K. (2015). Risk analysis in green supply chain using fuzzy AHP approach: A case study. Resources, Conservation and Recycling, vol. 104, 375-390, DOI: 10.1016/ j.resconrec.2015.01.001.

38. Leśniak, A., Kubek, D., Plebankiewicz, E., Zima, K., Belniak, S. (2018). Fuzzy AHP application for supporting contractors' bidding decision. Symmetry, vol. 10, no. 11, 642, DOI: 10.3390/sym10110642.

39. Polat, G., Eray, E., Bingol, B. N. (2017). An integrated fuzzy MCGDM approach for supplier selection problem. Journal of Civil Engineering and Management, vol. 23, no. 7, 926-942, DOI: 10.3846/13923730.2017.1343201.

40. Huang, B.-W., Yang, Y.-C. (2018). Evaluation Indicators and Development Strategies of Agricultural Revitalization for Rural Rejuvenation. Journal of Reviews on Global Economics, vol. 7, 269-279, DOI: 10.6000/1929-7092.2018.07.24.

41. Sari, D. P., Anwar, N., Sidharti, T. S. (2019). Analysis of Irrigation Modernization Pillars with Fuzzy Analytical Hierarchy Process (FAHP) Approachment.

42. Wijitkosum, S. (2018). Fuzzy AHP for drought risk assessment in Lam Ta Kong watershed, the north-eastern region of Thailand. Soil and Water Research, vol. 13, no. 4, 218-225, DOI: 10.17221/ 158/2017-SWR.

43. Deng, F., Zhang, X., Liang, X., Guo, Z., Bao, C. (2016), Earthquake disaster emergency supply chain performance evaluation based on triangular fuzzy numbers, in 2016 IEEE International Conference on Industrial Engineering and Engineering Management (IEEM): IEEE, p. 1483-1487, DOI: 10.1109/IEEM.2016.7798124.

44. Sabah, L., Yücedag, I., Yalcin, C. (2017). Earthquake Hazard Analysis for Districts of Düzce via AHP and Fuzzy Logic Methods. Cognitive Systems, vol. 2, no. 1. 
45. Timperio, G., Panchal, G. B., Samvedi, A., Goh, M., De Souza, R. (2017). Decision support framework for location selection and disaster relief network design. Journal of Humanitarian Logistics and Supply Chain Management, DOI: 10.1108/JHLSCM -112016-0040.

46. Kerkez, M., Gajović, V., Puzić, G. (2017). Flood risk assessment model using the fuzzy analytic hierarchy process. Progress in Economic Sciences, vol. 4, 271-282, DOI: 10.14595/PES/04/019.

47. Zou, Q., Zhou, J., Zhou, C., Song, L., Guo, J. (2013). Comprehensive flood risk assessment based on set pair analysis-variable fuzzy sets model and fuzzy AHP. Stochastic Environmental Research Risk Assessment, vol. 27, no. 2, 525-546, DOI: 10.1007/ s00477-012-0598-5.

48. Semarang, D. P. R. K. One Map Semarang, from https://distaru.semarangkota.go.id/semarang/index. php?webgis=tataruang\#, accessed on 2021-05-21.

49. Chandrawati, T. B., Ratna, A. A. P., Sari, R. F. (2020). Path Selection using Fuzzy Weight Aggregated Sum Product Assessment. International Journal of Computers, Communications \& Control, vol. 15, no. 5, DOI: $10.15837 /$ ijccc.2020.5.3978.
50. Helderop, E., Grubesic, T. H. (2019). Flood evacuation and rescue: The identification of critical road segments using whole-landscape features. Transportation research interdisciplinary perspectives, vol. 3, 100022, DOI: 10.1016/j.trip. 2019.100022.

51. Alonso, J. A., Lamata, M. T. (2006). Consistency in the analytic hierarchy process: a new approach. International journal of uncertainty, fuzziness and knowledge-based systems, vol. 14, no. 04, 445-459.

52. Zadeh, L. A. (1965). Fuzzy sets. Information and Control, vol. 8, no. 3, 338-353, DOI: 10.1016/S00199958(65)90241-X.

53. Chang, D.-Y. (1996). Applications of the extent analysis method on fuzzy AHP. European journal of operational research, vol. 95, no. 3, 649-655, DOI: 10.1016/0377-2217(95)00300-2. 